\title{
Shifting Ecological Imaginaries in the Ok Tedi Mining Crisis in Papua New Guinea
}

David Hyndman

\section{(2) OpenEdition \\ 12 Journals}

\section{Electronic version}

URL: http://journals.openedition.org/jso/396

DOI: $10.4000 /$ jso.396

ISSN: $1760-7256$

\section{Publisher}

Société des océanistes

\section{Printed version}

Date of publication: 1 December 2005

Number of pages: 76-93

ISSN: 0300-953x

\section{Electronic reference}

David Hyndman, "Shifting Ecological Imaginaries in the Ok Tedi Mining Crisis in Papua New Guinea », Journal de la Société des Océanistes [Online], 120-121 | Année 2005, Online since 27 November 2008 connection on 22 April 2019. URL : http://journals.openedition.org/jso/396 ; DOI : 10.4000/jso.396

\section{(c) Tous droits réservés}




\section{Shifting Ecological Imaginaries in the Ok Tedi Mining Crisis in Papua New Guinea}

par

David HYNDMAN*

\section{RÉSUMÉ}

Jusqu'à la fin des années soixante-dix, les systèmes de gestion de l'environnement par les propriétaires terriens de la haute rivière Ok Tedi en Papouasie NouvelleGuinée reposaient sur les possibilités d'accès et le contrôle des terres, des ressources et de l'eau. L'écologie de subsistance des années soixante-dix a fourni les éléments d'analyse des savoirs traditionnels concernant l'environnement et les droits et usages des ressources. Le projet minier d'Ok Tedi a vu le jour au début des années quatre-vingt. La mine est un projet à visée globale et les voies d'eau ont été soumises à rude épreuve au profit d'une gestion de l'environnement capitaliste et industrielle. Les propriétaires terriens de la région, vivant en économie d'autosubsistance à la périphérie de l'espace global, ont subi les affres de la transition complexe au capitalisme, face à des paysages ravagés par l'industrialisation; pour eux, ce fut une expérience tout à fait nouvelle. L'écologie politique des années quatre-vingt a permis l'analyse de l'appropriation des ressources et de leur utilisation dans un système de production capitaliste. L'écologie immorale de la mine a menacé l'écologie morale de subsistance et s'est jouée entre une vision globale versus locale des imaginaires de l'environnement équipés de différents pouvoirs et technologies. L'écologie de libération des années quatre-vingt-dix nous renseigne sur les analyses du potentiel libératoire d'un mouvement de résistance écologique populaire apparu en réponse aux sévères dégradations de l'environnement dues à la mine et qui menacent les moyens d'existence de plus de 30000 personnes vivant le long des rivières $O k$ Tedi et Fly. Aujourd'hui encore, cette crise minière, est caractérisée par des représentations conflictuelles de l'environnement entre mineurs, propriétaires terriens et chercheurs en sciences sociales.

Mots-CLÉS : Papouasie Nouvelle-Guinée, mine Ok Tedi, propriétaires terriens et chercheurs, écologie de subsistence, écologie politique, écologie de libération

\section{ABSTRACT}

Until the end of the 1970s, landowner systems of environmental management in the upper Ok Tedi River in Papua New Guinea were based on local access to and control over land, water and resources. Subsistence ecology in the 1970s informed the analysis of customary ecological knowledge and resource use and rights. The Ok Tedi mining project started in the early 1980s. The mine is global in scope and its harsh treatment of the river systems set aside for production is common to capitalist industrial environmental management. For local subsistence-oriented landowners at the periphery of global space, being in the throes of complex capitalist transition and destroyed industrial landscape was an alien experience. Political ecology in the 1980s informed analysis of resource appropriation and commoditisation into capitalist relations of production. The immoral ecology of the mine threatened the moral ecology of subsistence and was played out in global-local articulations between environmental imaginaries armed with different powers and technologies. Liberation ecology in the 1990s informed the analysis of the libratory potential of a popular ecological resistance movement that emerged in response to severe environmental degradation from the mine that threatened the livelihood of over 30,000 people along the Ok Tedi and Fly Rivers. Representations of the Ok Tedi mining crisis continue to be characterised by conflicting environmental imaginaries between miners, landowners and social scientists.

Keywords: Papua New Guinea, Ok Tedi mine, landowners and researchers, subsistence ecology, political ecology, liberation ecology

\footnotetext{
* Social Science Program, Bureau of Rural Sciences (Canberra), David.Hyndman@affa.gov.au
} 


\section{Subsistence Ecology}

«Cultural systems and ecosystems can be thought of as organised patterns for the processing of information, energy, and materials. The transfer of energy and materials from the ecosystem to the human system is primarily through culturally guided patterns of resource evaluation and exploitation. A subsistence system, then, is the assemblage of technologies and strategies with which humans modify and exploit energy relationships in order to tap and control biotic systems in the supply of energy and materials for human sustenance and maintenance.» (Nietschmann, 1973: 5)

I started environmental anthropology research with the Wopkaimin people of the upper Ok Tedi River in Papua New Guinea (PNG) in 1973. My concern was the ethnographic analysis of subsistence ecology, which comprehends people and environment as parts of a single system. The subsistence ecology study of Miskito Indians on the Caribbean coast of Nicaragua by Nietschmann provided general theoretical orientation to my research, and I followed his comprehensive definition of a subsistence system as:

«the organisation of production, distribution, and consumption of foods and other needed materials. The economy is characterised by reciprocal exchange patterns and kinship obligations, involving goods, favors and generosity. Production activities are formed around domestic units for family needs within a society structured by kinship. Reciprocity of goods and services is carried out between kinsmen and fellow villagers to the extent that what is "economic" is not easily distinguishable from the "social". Family pooling, reciprocity, and $\mathrm{a}[\mathrm{n}][\ldots]$ ethic that to be a good kinsman is to be unselfish, generous, and thoughtful toward others, all interrelate to provide a continuous circulation of labor, food, and materials within a village, the rate of which is geared by need and social relationship, not by Western economic cost accounting.» (Nietschmann, 1973: 61)

Clarke's (1971) classic subsistence ecology study of an isolated rural Melanesian community was very evocative of the locale and the features of Wopkaimin subsistence I encountered in my own research:

"An aesthetic attraction of the basin was the extraordinary steepness of the slopes that form the highest part of the rim; in places they rise almost vertically, so that the streams become water falls and the forested mountain crest with its dramatic massing of cloud seems to tower close above the homes and gardens of the basins lower slopes and floor.» (Clarke, 1971: 10)

"Though there are differences in the techniques used in shifting cultivation and some variation in the relative proportions of different crops, the important crops are everywhere the same: sweet potato, taro (Colocasia), Xanthosoma, sugar cane, Saccharum edule, bananas, yams, Pandanus conoideus, and a wide variety of vegetables. Gathering of wild foods, especially leaves, is significant. Animal protein is obtained by hunting and fishing and by raising tame cassowaries and the ubiquitous domestic pig.» (Clarke, 1971: 7)

I found Clarke's theoretical approach to understanding subsistence ecology to be particularly relevant and resonate well with my own research. In human ecosystems according to Clarke (1971: 18) «structure related both to the actual spatial arrangements of organisms and environmental elements and to the abstract connective organisation by means of which interactions take place. Function means the way that the parts of the system operate together and affect each other - that is, what is happening in the system». Moreover, I concurred with the stress Clarke placed on resilience over negative feedback functionalism:

"the idea of the ecosystem, which stresses the circularity of the relationship between organism and environment, make it easy to consider that environment as both a result of and an influence on human behaviour [...] Considered thus as components of an ecosystem, both man and the environment are seen as parts of a single unit, the whole of which is worthy of study. Concern shifts from which part most influences the other to the structure of the whole system and how it operates and changes... it removes the rear of the heresy of determinism in considering some human behaviour as adaptations to environmental conditions.» (Clarke, 1971: 200-201)

I carried out a collaborative ecological analysis (Hyndman and Menzies, 1980, 1990) that established the biotic resources endemic to the unique Ok Tedi ecosystem. Environmental imaginaries are experienced through a history of social relations particular to a natural environment, and they are mystically and spiritually expressed (Peet and Watts, 1998: 263). Having established a biotic resource reference point to the natural habitat, I examined how the Wopkaimin ethnoecological imaginary was embedded in the subsistence ecology of foraging, sago and taro swiddens (see Hyndman, 1979, 1982a, 1986; Hyndman and Morren 1990; Morren and Hyndman, 1987). Wopkaimin local histories of natural resource management were mapped onto a cultural landscape, with places metonymically representing important experiences in a person's life (Hyndman, 1991a). For subsistence-oriented Melanesians the ethnoecological imaginary envisions those forms of social practice that are ethically proper and morally right 
with regard to nature, which is an emic construct (see Peet and Watts, 1998: 263). Wopkaimin customary ecological knowledge and resource use and rights (Dwyer and Hyndman, 1983; Hyndman, 1984a; 1984b; Hyndman and Frodin, 1980) were embedded in what Dove and Kammen (1997) would identify as a system of moral ecology. Wopkaimin moral ecology management of the environment is morally right because of reciprocal relations with the environment. Moral ecology is like the notion of moral economy popularised by Scott. A moral economy is based on reciprocal social relations of production with goods and services that sustainably circulate internally within the society. Moral ecology is likewise based on sustainability with reciprocal cultural return to the local environment that has great time deapth.

\section{Political Ecology}

«Distinct forms of sociopolitical orgsanization are based on different production principles. For our purposes two types are of special importance: those based on subsistence, or simple reproduction, and those based on expanded production and private accumulation. The relevance to political ecology stems from the markedly different implications the two forms of organization have in terms of human appropriation of the natural environment.» (Schmink and Wood, 1987: 40)

The Ok Tedi mining project was created in 1981 under the Ok Tedi Mining Limited (OTML) consortium operated by Broken Hill Proprietary (BHP), the «Big Australian». PNG as combined resource owner and developer, took the subsoil minerals while being vague about indemnifying local landowners against natural resource degradation. Mining proceeded after 1984 without a tailings dam, producing large volumes of sediments saturated with heavy metals that flowed into the Ok Tedi River and past the d'Albertis Junction into the Fly River.

My personal "crisis of representation in anthropology» (see Marcus and Fischer, 1986), manifested as a growing distance between the kinds of research ethnographers write and the matters that concern the world at large, came with the start of the Ok Tedi mining project. Presenting an ethnographic present of the Wopkaimin in subsistence ecological isolation would have perpetuated exoticism at the expense of understanding the changing politics of cultural and ecological representation. The emerging conflict over natural resource management was mirrored in changing my research focus from subsistence ecology to political ecology «as the underlying social theory moves in poststructural directions and as new developments and tendencies occur in the politics of environment» (Peet and Watts, 1998: 36). Subsistence ecology, political ecology and liberation ecology are all etic categories theoretically operationalised by the researcher to conceptualise people and environment interrelationships. Moral ecology and immoral ecology are emic categories cognised by the Wopkaimin to account for people and environment interrelationships.

John Burton (1997), a consultant ethnographer from Pacific Social Mapping in Australia, astutely observed that a paradigm of terra nugax informed management practice of the Ok Tedi mine. This paradigm was not only lost on the local landowners who called their «discovered» cultural landscapes home, but it also misled managers to the politicised ecology in which mining was taking place. Peet and Watts (1998: 4) characterise political ecology «as perhaps the most important line of recent social scientific thinking about environment and development». Blaikie and Brookfield (1987: 17) combine the concerns of ecology and a broadly defined political economy and define political ecology as encompassing «interactive effects, the contribution of different geographical scales and hierarchies of socio-economic organisations (e.g. person, household, village, region, state, world) and the contradictions between social and environmental changes through time».

Political ecology accounts for articulations (see Wolpe, 1980) between the capitalist mode of production of the Ok Tedi mine and a series of non-capitalist modes in the local peripheries of Melanesia. The relationship between local landowners and the invading global mining frontier represents a conflict between subsistence production for simple reproduction (kinship mode of production) and extended production for private accumulation (capitalist mode of production). The expansion of mining meant that for the first time resources of the local landowners became commodities to be appropriated and exploited in capitalist relations of production. It is a legal peculiarity of Papua New Guinea, as a legacy of being an Australian colony, that the State assumes ownership of subsoil minerals. Subsoil resources were part of Wopkaimin material culture like ochres and stone for tools, and caves held a great deal of cultural improtance.

The political ecology of the Wopkaimin and the Ok Tedi mine is divided into an economic base and a derivative sociopolitical and ideological superstructure (Hyndman, 1994). 
The shifting ethnoecological imaginaries include those that are emic-based on moral and immoral ecology concepts among local indigenous peoples and those that are etic-based concepts on subsistence, political and liberation among the outside researchers. The economic base of the mining enclave imposed capitalist social relations of production on the Wopkaimin for the first time. It is the elite comprador bourgeoisie in PNG and the multinational OTML consortium that profit from the appropriation and exploitation of local landowner resources (Hyndman, 1988a) In terms of the derivative sociopolitical superstructure, the mining enclave developed instant townships and the Wopkaimin relocated to two new roadside villages adjacent to Tabubil where a clash developed between kinship and capitalist relations of production (Hyndman, 1987, 1997). Moreover, requirements from the Ok Tedi mine for capital, labour, and food for the workers, as well as the physical output of its operation, integrated and threatened the greater Ok Tedi and Fly River into a single socioecological sphere (Hyndman, 1991b). The superstructure of ideology constituted the main social protest of the Wopkaimin against the mining project (Hyndman, 1995).

There are some 3,500 Yonggom located mainly on the lower Ok Tedi River, and another 15,000 in West Papua where they have been ethnographically identified as the Muyu (Schoorl, 1993). When Stuart Kirsch (1996a) started fieldwork among the Yonggom in 1986 their subsistence-oriented ethnoecological imaginary based on foraging, sago and banana swiddens had not yet been destroyed. According to Gitawa Kambare, a Yonggom from Bige village:

«Here before it was a big lagoon and a big swamp, and there is the sago trees around and people used to get sagos there and we used to eat and satisfy. Most of our gardens were on the bank of the river, and the flood of the Ok Tedi River comes down and kills all the things in the garden.» (Fowler, 2000: 2)

The place/landscape of Yonggom memories (Kirsch, 1996a) are simultaneously inhabited by animals and other beings conceived of as having agency in ways comparable to humans (Kirsch, 2001). Resource degradation from the Ok Tedi mine has disturbingly caused memories once anchored by landscape to loose their moorings, to the point that the Yonggom now increasingly organize their accounts of the past in chronological sequence (Kirsch, 2001). The shift from spatial to temporal representation of experience represents a significant consequence of the $\mathrm{Ok}$ Tedi mine for the Yonggom. Symbolism remains a powerful repository of meaning only when the referents are familiar, with the disappearance of fish, birds and game, the conversations the Yonggom once had with the animals around them have all but ceased (Kirsch, 2001). Yonggom myth and ritual, no longer populated by animals, has degenerated to the level of an amusing folktale.

The Ok Tedi mine has restricted but not destroyed Wopkaimin continued use of their land and resources. PNG provides compensation mo9ney to the Wopkaimin because they are local landowners of Mt Fubilan where the Ok Tedi mine is located. Wopkaimin men assert control over compensation money, while the women control subsistence production (Hyndman, 1994). For the Yonggom the central social costs of environmental risk are not the production and distribution of commodities, but the management of hazards resulting from processes of production. By 1989, according to Junne Cosmas, a Yonggom from Erecta village:

«We knew that there was something wrong with the river when we saw changes in the plants and animals and whatever that surrounded our village or the river. The trees, they started changing colour, which normally they wouldn't change colour but those trees, they were changing colour and we knew something was wrong. And the good places that we go fishing, we couldn't catch much fish in those areas.» (Fowler, 2000: 6)

Since Yonggom productivity is no longer directly linked to the natural environment, they are displaced from living off the land to living off compensation from the mine (Kirsch, 2001). Yonggom compensation is not based on the use of their land and resources, but from the destruction of its productive capacity (Kirsch, 1996a). Once the mine closes the Yonggom can never return to their past (Kirsch, 1996a).

The moral ecology of subsistence production is jeopardized by the immoral ecology of mining. Mining represents an immoral ecology because it is unsustainable and there is no reciprocal return to the environment. The mine is global in scope and its harsh treatment of the lower Ok Tedi River set-aside for production is quite common to industrial natural resource management. In the collision of environmental imaginaries, the Ok Tedi mine attempts to transform the natural environment in ways that limit the effectiveness of other systems (Kirsch, 1997a: 132). Maun Tepke, a Yonggom villager, complains:

«a rich man came with a lot of money and he destroyed my environment. He got richer and made me poorer.» (Fowler, 2000: 1) 
The Yonggom compare the mine and its impact on their environment to immoral sorcery and its harmful effects (Kirsch, 1997a). Sorcery is negative reciprocity and the mine is considered irrational and dangerous like sorcery. The Yonggom use sorcery accusations to hold people accountable for their actions, it is a form of social control. Cause and effect within sorcery links inappropriate behaviour with loss or mishap, thus Yonggom claims against the mine represents a moral assertion that pairs destructive environmental impact with specific cases of misfortune (Kirsch, 1997a). The Yonggom reject the view that the mine's liability is limited to material terms, their discourse is recast as a moral issue.

\section{Liberation Ecology}

«Liberation ecology integrates critical approaches to political economy with notions derived from poststructural philosophy. It speaks to a critical analysis of environmental degradation and rehabilitation framed by something called development, and also the liberatory potential of struggles and conflicts exacted around these processes.» (Peet and Watts, 1998: 260)

By the 1990s weak environmental protection plans, coupled with sedimentation and a long series of ecological disasters associated with the mine, endangered the natural resources and livelihood of over 30,000 landowners downstream of the mine (Hyndman, 2001). The Yonggom were faced with an unprecedented annual assault of 30 million tonnes of tailings and 40 million tonnes of waste rock entering the river system resulting in 140 kilometres of forest dieback and natural resource degradation.

Rather than accept the compensation terms brokered by the Ok Tedi mine and PNG, the Yonggom embarked on a series of global journeys in which they successfully challenged the mine in a precedent-setting legal battle and in the court of global public opinion. The great achievement of the Yonggom is that they became leaders of a global alliance to stop pollution from the Ok Tedi mine (Kirsch, 1996b). They initiated a popular ecological resistance movement that had as its core an environmental imaginary at odds with the hegemonic conception from the Ok Tedi mine.

The processes by which environmental imaginaries are formed, contested, and practiced in the course of specific trajectories of political economic change informs liberation ecology. One of the great merits of the turn to discourse is the demand it makes for a liberation ecological thick description.

Yonggom autonomous control of their natural environment beneath layers of landscape, place, aesthetics and subsistence increasingly became dependent on their effectiveness as global political activists (Kirsch, 1997b). The Yonggom demonstrated their ability to communicate their concerns to a national and international audience. A new class of political leaders emerged, Rex Dagi and Alex Maun especially, and they developed effective strategies of political engagement (Kirsch, 1996b; Maun, 1994). According to Kirsch (1996b: 15):

«Two Yonggom leaders, Rex Dagi and Alex Maun, stand out in the challenge against [...] BHP [...] assisted by the Wau Ecology Institute in Papua New Guinea, Dagi and Maun presented their case against the $\mathrm{Ok}$ Tedi mine to the International Water Tribunal in The Hague. Invited to Bonn by several church groups, they urged German shareholders in the mine to press for environmental reform. Dagi attended the 1992 Earth Summit in Rio de Janeiro, while Maun recently spoke to indigenous leaders in northern Canada regarding BHP's bid to gain the concession for a diamond mine.Through these experiences, they have developed a broader understanding of thier standoff with the mine, and have become capable political leaders.»

Threats to human livelihood and health remain the most important reasons for the global emergence of popular ecological resistance movements (Taylor, 1995) like the protest initiated by the Yonggom. Success of the Yonggombased coalition of 30,000 landowners, anthropologists, and NGO-based environmentalists in popular ecological resistance was unified global interconnections in political response to the $\mathrm{Ok}$ Tedi mine.

An alien tort was spearheaded by the Yonggom that held the Ok Tedi mine accountable in its home country of Australia for their environmental impact in PNG. Foreign or alien torts is the mechanism deployed by the popular ecological resistance movement to make BHP accountable in the country where corporate headquarters are based. The foreign tort held the multinational BHP responsible for in its home country for its environmental impact overseas in PNG. The Ok Tedi case had difficulty establishing jurisdiction claims relating to loss and/or damage to land. Therefore, the alien tort was reframed to loss of amenity, which established that Yonggom subsistence production was as equally as 'economic' as capitalist mining production (Kirsch, 1997b). An influential out of court settlement was made against the Ok Tedi mine in 1996. The settlement was significant 
because it offered an alternative to violence, it stimulated environmental debate, and it galvanized global alliances (Kirsch, 1997b). Compensation in the out of court Ok Tedi settlement amounted to an estimated Us500 million in commitments to compensation and tailings containment (Banks and Ballard, 1997), and any disputes in implementation were to be heard by the Victorian Supreme Court in Melbourne.

In terms of the emancipatory potential of environmental ideas, I agree with Taylor (1995b) that common emancipatory denominators can promote the convergence of interests between radical environmentalists and popular ecological resistance movements. One commonality in global linkage and local resistance to the Ok Tedi mining crisis was to view growth and industrialisation as illusions offered by elites to keep local peoples from promoting appropriate and sustainable alternatives. Another commonality was to reject industrial lifeways, defend and restore the commons and the democratic impulse to return decision-making to local people. A final commonality envisioned the libratory movement neither overthrowing nor withering away of the State, but wresting concessions to protect and reclaim access to resource control, while securing State and multinational compliance with such concessions.

\section{Contested Environmental Imaginaries}

«[...] the positioning of anthropologists within these "resource wars" (Gedicks, 1993) is far from simple, and a parallel war of sorts is being waged within the discipline about the nature and scope of appropriate forms of engagement.» (Ballard and Banks, 2003: 289)

Liberation ecology anticipates debate and discourse over nature and modernity, and the emancipatory potential of environmental ideas (Peet and Watts, 1998: 37). Hyndman (2001) and Kirsch $(1997,2002)$ stress the high environmental cost of mining and privilege the emancipatory potential of the popular ecological resistance movement to explain social conflict surrounding the Ok Tedi mine over the distribution of economic benefits. The argument is that liberation ecology debates nature and modernity an is certainly not solely concerned with the environment. This critical etic approach speaks to environmental degradation and development and the struggles and processes exacted around these processes. Ballard and Banks (2003: 299) challenge that I have singled out ecological from other community interests, which is condemned as a «curiously archaic argument». The politi- cised debate over the relative merits of environmental and economic explanations has become surprisingly rancorous.

Banks (2002: 39) on one hand acknowledges that «controversies linked with the large-scale mines in Melanesia largely revolve around the environmental impact of their waste management strategies on the communities living downstream of the mine, yet I am chastised for framing mining impacts as solely an environmental or ecological problem» (my emphasis). Furthermore (Banks, 2002: 59), facetiously ponders if «the effects on the environment mean that the resulting community impacts should be glossed solely as environmental problems»?

King (1997) blames me personally for creating the negative image of the Ok Tedi mine. I am wrongly accused by Banks (2002: 41, 59) of mounting a «scathing» attack, while assuming the «moral high ground», and he appeals to semantics to reframe that «the use by Kirsch and Hyndman of the terms ecological and environmental resonates with Eurocentric baggage - of an environment that is external to, and separate from, people's daily lives - and hence too limiting to encompass an indigenous perspective of the problems and changes these communities face» and that «Hyndman and Kirsch are able to tap into a strong international vein of environmental rhetoric that is more readily accepted and so more likely to attract support in the developed world than a discourse of community development and livelihoods» (Banks, 2002: 42). Ballard and Banks (2002: 299) misrepresent that I have prioritised environmental concerns over other interests in order to resonate with western notions of indigenous ecological stewardship. Banks' (2002: 41) even makes the disingenuous appeals to «a more robust and widely applicable framework [...] in which political ecologists are increasingly incorporating the notion of environment into a framework of human livelihood».

In Resource Wars: The Anthropology of Mining, Ballard and Banks (2003: 299) indicate they have not prioritised narrow economic over ecological interests, then endorse a similar broader social frame of reference centred on resource control that acknowledges the environmental destruction of mining and the emancipatory potential of ecological resistance movements:

«Our intention is not to replace an ecological basis for protest with narrowly defined economic interests [...] but is rather to suggest that a concern with control over fundamental questions of community sovereignty is expressed through a multitude of channels and means and must often appeal to more powerful (and 
often western) audiences through the most potent and familiar tropes, such as abuses of basic human rights or environmental destruction.» (Ballard and Banks, 2003: 299)

Unnecessarily «warlike» debate fails to acknowledge that my political ecology analysis is enmeshed in wider social issues. Nowhere in my studies of subsistence, political and liberation ecology have I been environmentally deterministic, nor have I pandered to western notions of the ecological noble savage. I certainly cannot claim credit for the environmental vandal image of the Ok Tedi mine, nor for creating the popular ecological resistance movement. I have deployed subsistence ecology, political ecology and liberation ecology in my continuing analysis of global linkage, local resistance and shifting ethnoecological imaginaries surrounding the $\mathrm{Ok}$ Tedi mine. Far from being environmental deterministic and eschewing social context, I have shown that articulations between societies can be expressed as the interaction between environmental imaginaries armed with different powers and technologies (see Hyndman, 2001).

In terms of the emancipatory potential of environmental ideas, mitigating environmental impact unfortunately proved to be ineffectual. In June 1996 an out of court settlement was reached and committed the mining company to implementing a feasible tailings containment system, paying K40 million by way of compensation to the worswt affected areas on the Ok Tedi, and to paying K110 million to all affected persons. The value of the settlement has been reduced enormously by the devaluation of the PNG kina and the lack of expenditure on tailings containment. Attempting to rely on their out of court cash settlement has proven difficult because the benefits are often superficial. Since settlement June Cosmas, a Yonggom from Erecta village at the confluence of the Ok Tedi and Fly rivers, has received just 200 kina (A \$100) compensation:

«With 200 kina I can buy 20 kilos of rice, maybe about 10 large tinned fish, bully beef maybe 10, sugar maybe five and maybe one or two odd things. We can't get a lot. And that would be the last, maybe for two weeks, and it's gone. You know that's all the money.» (Fowler, 2000: 17)

The popular ecological resistance movement came too late to save the river and the surrounding forests. Environmental studies released by the Ok Tedi mine in 1999 indicated that, even with immediate termination of mining, environmental problems downstream of the mine will continue to increase and will persist for at least
50 years. Tailings and mine waste migrating downstream have caused $500 \mathrm{sq} \mathrm{km}$ of deforestation and may eventually affect 1,500-3,000 sq km (Paramix, Inc 1999). With the mine continuing to deliver sedimentation, copper and acid rain drainage assaults on the river, management declared the Ok Tedi mine to be «a dysfunctional aspect of" of BHP's portfolio» (Fowler, 2000: 5).

Landowners in the popular ecological resistance movement returned to the Victorian Supreme Court in Melbourne in April 2000 to file another class action suit suing BHP for breaching previous settlement terms. The intention was to stop BHP Billiton from walking away from the Ok Tedi mine, compel tailings containment and obtain punitive damages for failing to limit environmental impact. In February 2002 BHP finally walked away from the Ok Tedi mine transferring its $52 \%$ equity stake to the PNG Sustainable Development Program Ltd., and receiving full indemnity against future environmental prosecution in PNG.

The Ok Tedi suit was settled in December and ratified by the Supreme Court of Victoria in January 2004. Ok Tedi managing director Keith Faulkner said "the continued operation of the mine is in the interests of those landowners and for PNG as a whole, as Ok Tedi is one of the largest businesses in the country, making a sizable contribution in terms of taxes ands royalties" (ABC Online, 2004). According to Kirsch (2004: 52):

«Instead of facilitating the early closure of the mine, BHP Billiton transferred its 52 percent ownership stake to an independent trust company that will support development projects in Papua New Guinea, allowing the mine to continue operating as before. The letterwriters from the affected communities are critical of the Australian company's departure.»

The status of the 30,000 people purportedly represented by the opt-out notice is unclear. Many landowners rejected the implicit trade-off between development and the right to a healthy environment, and the number of persons who objected to the settlement is far greater than the number of persons represented by the letters sent to the courts in January 2004 (Kirsch, 2004). In a review for Oxfam Australia the dean of the University of Papua New Guinea Law School, Lawrence Kalinoe, found the agreement failed to meet the legal threshold for informed consent. Slater and Gorton collected many affidavits challenging the opt-out notices, and the Mineral Policy Institute indicated several communities along the river "vehemently rejected the settlement" (The Age, 2004). The settlement 
does not accurately represent the will of all communities.

Until the end of the 1970s, landowner systems of environmental management in the upper Ok Tedi River in Papua New Guinea were based on local access to and control over resources. The Ok Tedi mine started in the early 1980s. For local subsistence-oriented landowners at the periphery of global space, being in the throes of transition to capitalist relations of production and destroyed industrial landscape has been an alien experience. Over three decades I have variously used subsistence, political and liberation ecology to analyze the changing people and environment interrelationships in the region. Cultural and political representations of the Ok Tedi mining crisis continue to be characterized by conflicting environmental imaginaries between miners, landowners, and social scientists.

\section{BIBLIOGRAPHY}

ABC Online, 2004.Ok Tedi lawsuit against BHP dropped http://www.abc.net.au/news/newsitems/ s1026850. htm.

Age, 2004. Ok Tedi class action dismissed http://www. theage.com.au/2004/01/16/1073878028901.html.

BAnks G., 2002. Mining and the Environment in Melanesia: Contemporary Debates Reviewed, The Contemporary Pacific 14, 1, pp. 39-67.

Burton John, 1997. Terra Nugax: Mining and the Discovery Paradigm, In Banks G. and C. Ballard (eds), The Ok Tedi Settlement: Issues, Outcomes and Implications, Pacific Policy Paper 27, National Centre for Development Studies, Canberra, Australian National University, pp. 27-55.

Clarke William C., 1971. Place and People: An Ecology of a New Guinea Community, Canberra, Australian National University.

Dove M. and D. Kammen, 1997. The Epistemology of Sustainable Resource Use: Managing Forest Products, Swiddens, and High-Yielding Variety Crops, Human Organization 56, 1, pp. 91-101.

Dwyer Peter and David Hyndman, 1983. Frog and Lizard: Additional Life Forms from Papua New Guinea. American Anthropologist 85, pp. 890-896.

Fowler Andrew, 2000. After the Gold Rush. Four Corners, 10/4/00: Australian Broadcasting Corporation http://abc.net.au/4corners/stories/ s117535.htm (accessed 11 April 2000).

Gedicks A., 1993. The New Resource Wars: Native and Environmental Struggles Against Environmental Corporations, Boston, South end.

Hyndman David, 1979. Wopkaimin Subsistence: Cultural Ecology in the New Guinea Highland Fringe,
Unpublished PhD thesis, Brisbane, University of Queensland.

-, 1982a. Biotope Gradient in a Diversified New Guinea Subsistence System. Human Ecology 10, pp. 219-59.

-, 1984a. Hunting and the Classification of Game Animals among the Wopkaimin, Oceania 54, pp. 289-309.

_, 1984b. Wopkaimin Pandanus: Ethnobotany of a Significant Papua New Guinea Plant Resource, Economic Botany 38, pp. 287-303.

—, 1986. Men, Women, Work and Group Nutrition in a New Guinea Mountain Ok Society, in Manderson L. (ed.), Shared Wealth and Symbol: Food, Culture and Society in Oceania and Southeast Asia, New York, Cambridge University Press, pp. 29-48.

_, 1987. Mining, Modernisation and Movements of Social Protest in New Guinea, Social Analysis 21, pp. 20-38.

—, 1988a. Ok Tedi: New Guinea's Disaster Mine, The Ecologist 18, 1, pp. 24-29.

_, 1991a. The Kam Basin Homeland of the Wopkaimin: A Sense of Place, in Pawley A. (ed.), Man and a Half: Essays in Pacific Anthropology and Ethnobiology in Honour of Ralph Bulmer, Auckland, University of Auckland Press, pp. 246-256.

-, 1991b. Zipping Down the Fly on the Ok Tedi Project, in Connell J. and R. Howitt (eds), Mining and Indigenous Peoples in Australasia, Sydney, University of Sydney Press, pp. 77-90.

_, 1994. Ancestral Rain Forests \& the Mountain of Gold: Indigenous Peoples and Mining in New Guinea, Boulder, Westview Press.

_, 1995. Afek and Rebaibal: Ideologies of Social Protest and the Ok Tedi Mining Project in Papua New Guinea, Journal of the Polynesian Society 104, pp. 75-88.

- 1997. Changing Relations of Production in the Creation of the Ok Tedi Mining Enclave in Papua New Guinea, Resource Management in Asia-Pacific Project Working Paper 11, RSPAS, Australian National University.

_, 2001. Academic Responsibilities and Representation of the Ok Tedi Crisis in Postcolonial Papua New Guinea, The Contemporary Pacific 13, 1, pp. 33-54.

Hyndman David and James Menzies, 1980. Aproteles bulmerae (Chiroptera: Pteropodidae) of New Guinea is not Extinct, Journal of Mammalogy 61, pp. 159-160.

_, 1990. Rain Forests of the Ok Tedi Headwaters: An Ecological analysis, Journal of Biogeography 17, pp. 241-273.

Hyndman David and George Morren, 1990. Human Ecology of the Mountain Ok of Central New Guinea: A Regional and Inter-Regional Approach, in Craig B. and D. Hyndman (eds), Children of Afek, Sydney, Oceania Monographs, pp. 9-26. 
KIRSCH Stuart, 1996a. Return to Ok Tedi, Meanjin 55, 4, pp. 657-666.

—, 1996b. Anthropology and Global Alliances: Comment, Anthropology Today 12, 4, pp. 14-16, 26.

_, 1997a. Indigenous Response to Environmental Impact along the Ok Tedi River, in Susan Toft (ed.), Compensation for Resource Development, Papua New Guinea Law Reform Commission Monograph 6/Pacific Policy Paper 24, Law Reform Commission and National Centre for Development Studies, Port Moresby and Canberra, Australian National University, pp. 143-155.

_, 1997b. Is Ok Tedi a Precedent? Implications of the Lawsuit, in Glenn Banks and Chris Ballard (eds), The Ok Tedi Settlement: Issues, Outcomes and Implications, Resource Management in AsiaPacific, and Pacific Policy Paper 27, National Centre for Development Studies, Canberra, Australian National University, pp. 118-40.

_, 2001. Changing Views of Place and Time along the Ok Tedi, in Rumsey A. and James Weiner (eds), Mining and Indigenous Lifeworlds in Australia and Papua New GuineaI. Adelaide: Crawford House, pp. 182-207.

—, 2002. Anthropology and Advocacy: A Case Study of the Campaign against the Ok Tedi Mine, Critique of Anthropology 22, 2, pp. 175-200.

—, 2004. No Justice in Ok Tedi Settlement, Cultural Survival Quarterly 28, 3, pp. 52-53.

MARCus George and Michael FisCHER, 1986. Anthropology as Cultural Critique: An Experimental Moment in the Human Sciences, Chicago, University of Chicago Press.

Maun Alex, 1994. Ok Tedi Mining: Human and Environmental Tragedy, in Schoell H. (ed.), Development and Environment in Papua New Guinea: An Overview, Point Series 18, Goroka, The Melanesian Institute, pp. 87-97.

Morren George and David Hyndman, 1987. The Taro Monoculture of Central New Guinea, Human Ecology 15, pp. 301-315.

PARAmix Inc. and URs Greiner Woodward Clyde, 1999. Draft Executive Summary: Assessment of Human Health and Ecological Risks for Proposed Mine Waste Mitigation Options at the Ok Tedi Mine, Papua New Guinea, pp. 1-15 (available at: www.oktedi.com).

Nietschmann Bernard, 1972. Between Land and Water: The Subsistence Ecology of the Miskito Indians, Eastern Nicaragua, New York, Seminar Press.

PEET Richard and Michael Watts, 1998. Liberation Ecologies: Environment, Development, Social Movements, London, Routledge.

SCHOORL Johan, 1993. Culture and Change among the Muyu, translated by G.J. van Exel, KITLV Translations Series 23, Lieden, KITLV Press.

TAYloR Bron, 1995. Popular Ecological Resistance and Radical Environmentalism, in Taylor Bron (ed.), Ecological Resistance Movements: The Global Emergence of Radical and Popular Environmentalism, Albany, State University of New York Press, pp. 334-354.

TAYLOR Bron (ed.), 1995. Ecological Resistance Movements: The Global Emergence of Radical and Popular Environmentalism, Albany, State University of New York Press.

WolPE Harold (ed.), 1980. The Articulation of Modes of Production, London, Routledge. 



\section{Waiting for company or waiting for god? L'application du modèle du giving environment aux Oksapmin de Papouasie Nouvelle-Guinée}

par

Lorenzo BRUTTI*

\section{RÉSUMÉ}

Dans cet essai, l'auteur applique le modèle de Nurit Bird-David d' "environnement généreux », ainsi qu'il a été utilisé par Peter Dwyer et Monica Minnegal pour les Kubo, aux Oksapmin, une société d'agriculteurs et chasseurs qui habitent les forêts de montagne de l'intérieur de la Papouasie Nouvelle-Guinée. Trois principaux agents externes ont affecté, pendant les dernières décennies, l'usage de la nature et le rapport à l'environnement forestier à Oksapmin: le processus d'évangélisation, la présence de l'administration gouvernementale australienne et l'impact des compagnies minières. L'auteur décrit de quelle façon des changements idéologiques peuvent profondément influencer les représentations écologiques et les pratiques sur l'environnement.

Mots-CLÉS : Oksapmin, Min, Mélanésie, Papouasie Nouvelle-Guinée, écologie, environnement, forêt, rituel, sacrifice humain, évangélisation, christianisme, millénarisme, compagnies minières, développement.

Il semblerait que Samuel Beckett soit une source d'inspiration pour certains anthropologues travaillant en Papouasie Nouvelle-Guinée, comme Peter Dwyer, Monica Minnegal et l'auteur de cet essai, qui ont tous paraphrasé le titre de l'une des pièces les plus connues de cet

\begin{abstract}
In this essay the author apply the Bird-David's model of "giving environment» as used by Peter Dwyer and Monica Minnegal for the Kubo, to the Oksapmin, a society of hunters and agriculturalists living in the mountain forests of Papua New Guinea. Three main agents of change have interested that area during the last decades and affected the use of nature and the relationship with the forest environment : the conversion to Christianity, the presence of Australian administration and the impact of mining companies in the area. The author describe how the ideological changes may deeply affect the ecological representations and the environmental practices.
\end{abstract}

Keywords: Oksapmin, Min, Melanesia, Papua New Guinea, ecology, environment, forest, ritual, human sacrifice, conversion, Christianity, Millenarism, mining companies, development. auteur irlandais pour intituler l'un de leurs articles (Brutti, 1997 ; Dwyer and Minnegal, 1998). À partir de ces écrits, je voudrais analyser les concepts de « développement » et « occidentalisation » dans le modèle défini par Peter Dwyer et Monica Minnegal et essayer de les appliquer aux

* Ethnologue, ums cNRs 1834/Musée du Quai Branly, lorenzo.brutti@cnrs-dir.fr 
Oksapmin, parmi lesquels j'ai travaillé pendant trois ans ${ }^{1}$. Bien que l'histoire du développement des Kubo et des Oksapmin soit sensiblement différente, je voudrais néanmoins tracer un parallèle entre les représentations, dans ces deux sociétés, des mêmes entités exogènes que sont les missionnaires, les anthropologues et les compagnies minières, tous perçus comme vecteurs du changement.

\section{Un modèle exportable ?}

L'un des éléments les plus intéressants dans la réflexion de Peter Dwyer et Monica Minnegal est l'emploi du modèle du giving environment ${ }^{2}$ que l'on pourrait maladroitement traduire en français par «environnement généreux». $\mathrm{Ce}$ concept est inspiré du travail de Nurit BirdDavid (1990) qui, en offrant une nouvelle approche à l'analyse du système économique des chasseurs-cueilleurs d'après ses travaux chez les Nayaka de l'Inde méridionale ainsi que chez les Pygmées Mbuti et les Negritos Batek, soutient que les dites sociétés perçoivent leur environnement forestier comme un « parent éternellement pourvoyeur » fournissant de la nourriture à ceux qui en demandent sans attendre quoi que ce soit en échange. L'auteur intègre cette représentation des relations entre les êtres humains et la nature à celle des relations entre certains agriculteurs ou agriculteurs-chasseurs chez lesquels la nature est perçue comme fournissant de la nourriture en échange d'une bonne conduite, de façon que les gens et leur environnement sont liés entre eux par des relations de responsabilité mutuelle (Bird-David, cité par Dwyer and Minnegal, 1998 : 29). Chez les Kubo étudiés par Peter Dwyer et Monica Minnegal, cette autonomie d'action s'articule entre l'aptitude à partager (sharing in) les ressources et celle à repartir (sharing out) les produits à l'extérieur. C'est dans ce sens que Peter Dwyer et Monica Minnegal ont recours à l'idée de good company (« bonne compagnie ») telle qu'elle a été énoncée par Bruce Knauft (1985), car c'est à travers le partage que la bonne compagnie peut être atteinte. Dans cette approche, c'est l'importance du retour immédiat, de la réciprocité, qui offre la possibilité de comprendre plusieurs aspects de la vie sociale des Kubo. Mais, puisque le modèle économique d'environnement généreux implique les concepts de réciprocité généralisée et d'immédiateté, il est de ce fait vulnérable, puisque tous les nouveaux venus ont déçu les attentes des Kubo. Dans leur cas, en fait, les attentes, engendrées comme conséquences des premières rencontres avec la modernité, n'ont pas été remplies et la déception qui s'en suivit a provoqué la croissance d'un sentiment de marginalité.

Dans le cas des Oksapmin, l'impact de la modernité sous forme de compagnie minière et d'églises missionnaires a apporté des conséquences positives tangibles, au moins sur le court terme. Mais, ces bénéfices volatiles peuvent évoluer, comme pour les Kubo, vers un sentiment de déception et de marginalité, si les conséquences de la présence des compagnies minières et des églises décroissent. Les Oksapmin ont réagi aux changements introduits par la modernité en transformant les modes d'appropriation des ressources naturelles : par exemple, en développant les cultures de produits destinés essentiellement au marché de Tabubil, siège de Ok Tedi Mining Limited ou en revendiquant, auprès de Porgera Joint Venture, des droits fonciers comme conséquence de l'impact écologique sur le fleuve Strickland qui délimite pour une large partie les frontières du territoire oksapmin.

L'approche écologique contemporaine des Oksapmin semble se prêter particulièrement à l'interprétation $\mathrm{du}$ modèle d'environnement généreux énoncé par Nurit Bird-David, qui est assez éloignée de celle de l'ethnoécologie occidentale. En fait, chez les Oksapmin, il n'y a pas de discours émique sur le management environnemental à long terme. Les Oksapmin revendiquent le droit d'exploiter leur environnement, y compris leurs rivières et les forêts environnantes. Leur attente pourrait être définie avec les mêmes termes par lesquels Peter Dwyer et Monica Minnegal (1998: 34) ont décrit les attentes des Kubo : les biens et l'argent couleraient à flots des compagnies vers les membres de la communauté en créant des circonstances favorables à l'emploi. Les autochtones tireraient profit de la situation en « exploitant» la compagnie sans néanmoins adopter une attitude très critique envers elle. Si les Oksapmin agissent d'une façon stricte et sévère en matière d'écologie, ils craignent que la compagnie parte et, qu'avec elle, s'envole, aussi la possibilité d'enrichissement : le train pour le développement serait alors raté ! Il n'est donc pas difficile de comprendre pourquoi la majorité

1. De mars 1995 à février 1996 (douze mois); de septembre 1996 à avril 1997 (huit mois), de février à octobre 1998 (neuf mois), de novembre 1998 à février 1999 (quatre mois); de décembre 1999 à janvier 2000 (deux mois), pour un total de trente-cinq mois environ sur cinq différents séjours entre 1995 et 2000.

2. Dans le texte, les termes en langues anglaise et vernaculaire seront identifiés en italiques, les termes en langue véhiculaire seront soulignés. 


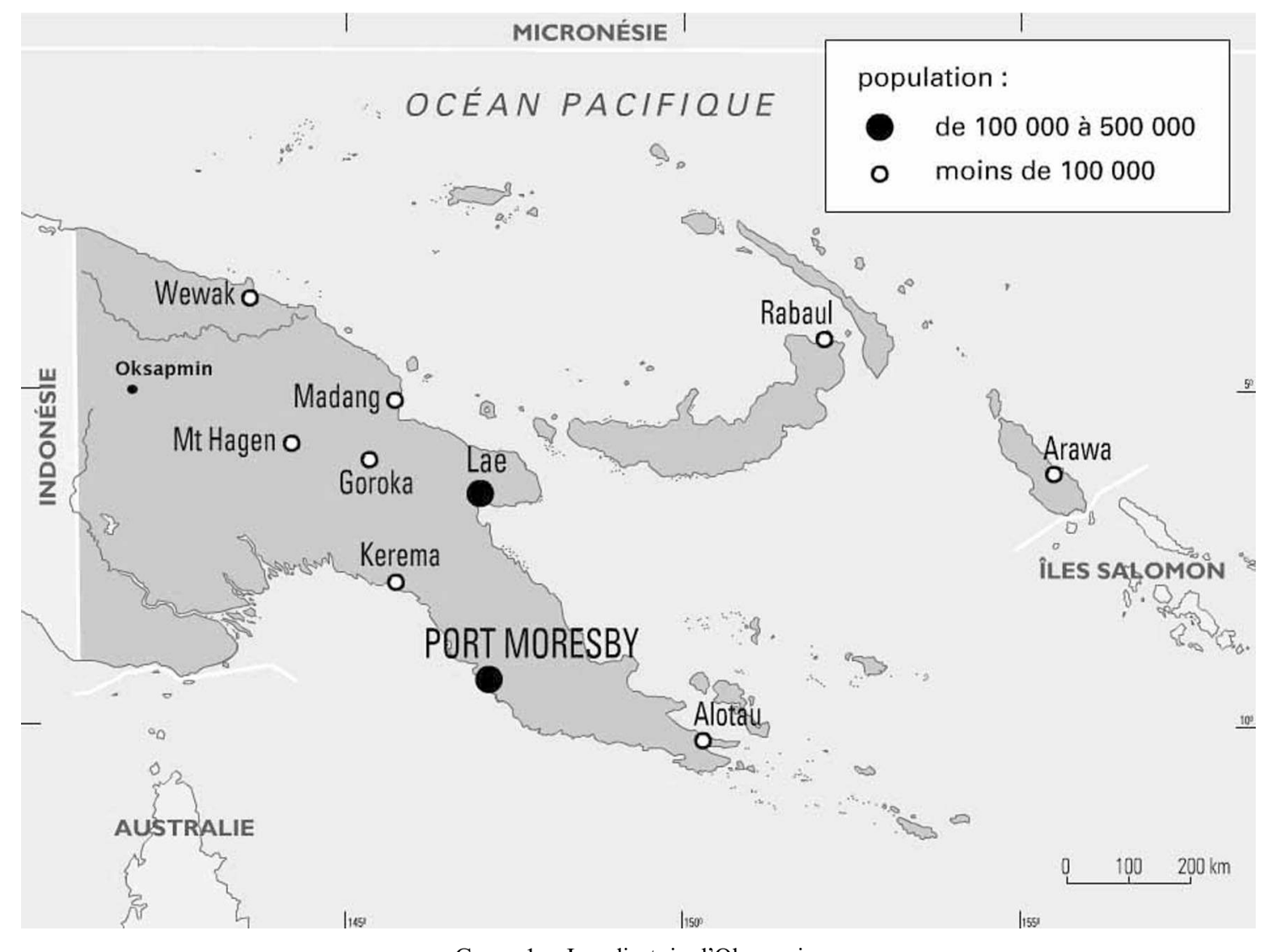

CARTE 1. - Localisatoin d'Oksapmin.

des autochtones est favorable à la présence des compagnies minières.

Un tel comportement pourrait être partiellement expliqué par les changements cosmologiques récents qui ont caractérisé la société oksapmin, plus dans sa dimension rituelle que dans sa dimension politique. En fait, il y une continuité relative au mode de succession du leadership à travers le temps : dans la société oksapmin précontact, le rôle de leader était joué par des spécialistes rituels ; aujourd'hui, ce même rôle est joué par les pasteurs des Églises locales, qui sont parmi les plus importantes arènes de pouvoir contemporain. Les pasteurs locaux -souvent les enfants des leaders coutumiers précédents -, sont aujourd'hui des notables oksapmin. Cela ne signifie pas que le pouvoir et le leadership sont systématiquement héréditaires, mais il arrive souvent que le fils d'un homme important continue le travail politique de son père sous une autre forme, dans un autre contexte. Si cela ne se produit pas, cette « position vacante » sera occupée par un nouveau, jeune, brillant self-made man. Étant donné que le gouvernement australien a mis fin à l'état de guerre dans la région depuis les années 1960 et que les Églises protestantes et adventistes ont interdit toute forme de comportement rituel à partir de la même époque, l'exercice oksapmin du leadership a trouvé son expression dans les nouveaux modèles importés des formes politiques et religieuses, l'économie de marché créée par la présence des compagnies privées et le culte chrétien avec sa philosophie, notamment la doctrine du libre arbitre.

À Oksapmin existaient auparavant des formes de comportement directement dirigées vers la conservation des ressources naturelles, dont le point culminant était un culte de fertilité appelé Yuan täl, basé sur un sacrifice humain (Brutti, 1997, 2003). Ces rituels ont été abandonnés aujourd'hui. Il existait aussi des formes traditionnelles de comportement visant indirectement à la préservation des ressources naturelles : les tabous concernant l'abattage des arbres autour des pandanus, la chasse de certains animaux ou la consommation de certains fruits de plantes non cultivées. Les Oksapmin reconnaissent différents types de sites sacrés (awam ap ou awam mong): maisons cérémonielles, chemins mythiques relatifs au rituel du Yuan täl. Plusieurs de ces sites se trouvent sur les berges du fleuve Strickland. Les dernières cérémonies d'initiations masculines ont eu lieu à Oksapmin 
en 1960 et, depuis, elles ont été formellement interdites par la censure active des évangélistes, notamment de l'Australian Baptist Mission de Tekin. Ces activités culturelles avaient, bien sûr, une importance fondamentale pour la transmission de la culture. À cause de l'abandon de ces pratiques rituelles, la culture oksapmin, comme plusieurs autres cultures néo-guinéennes, a sensiblement changé en perdant sa cohérence écologique. D'ici quelques décennies à peine, quand la totalité des hommes initiés aura disparu, il n'y aura plus d'individus compétents pour transmettre la connaissance écologique de l'environnement, dont l'action rituelle était indissolublement imprégnée. Malheureusement, cette période coïncidera probablement, à quelques années près, avec la fin des opérations des compagnies minières dans la région. À cette époque, un nombre important de travailleurs des mines seront obligés de rentrer vivre dans leur village d'origine et de baser leur économie de subsistance sur l'agroforesterie. Ces individus auront perdu les compétences écologiques de leurs grands-parents.

\section{Un développement transformateur}

Les Oksapmin aujourd'hui sont massivement convertis à la religion chrétienne et perçoivent la religion traditionnelle comme négative. Les sites sacrés ont été détruits pendant le processus d'évangélisation et les portions de forêt primaire, qui étaient interdites à l'agriculture dans le passé, sont aujourd'hui cultivées massivement. Les Oksapmin se préoccupent peu de la préservation de l'environnement forestier, alors que le bassin des rivières des basses terres, surtout le Strickland, est réputé en danger à cause de l'érosion et de la pollution chimique provoquées par les opérations de l'une des compagnies minières actives dans la région.

Le discours écologique des Oksapmin présente des différences importantes, en fonction des générations, qui sont encore plus marquées sexuellement, en fonction du genre. En matière d'écologie en effet, les hommes ont, par rapport aux femmes, une priorité d'expression, conséquence de la domination masculine qui continue à s'imposer malgré le glissement d'un modèle socioculturel coutumier pré-contact vers un modèle occidental. La persistance de cette domination est probablement due au fait que les hommes ont été, pendant les premières décennies du contact, les principaux bénéficiaires de l'éducation supérieure et pratiquement les seuls acteurs de l'émigration. Les femmes n'ont pas pu émi- grer comme travailleurs des compagnies ni acquérir de diplômes universitaires faute de financement de la part de leurs familles. Une autre raison est probablement liée à la division sexuelle du travail. Dans plusieurs foyers, à cause de l'émigration masculine, les femmes ont souvent dû assumer une charge supplémentaire de travail. Mais ce qui a changé pour les femmes oksapmin est leur implication croissante dans l'action religieuse à cause de la conversion. En comparaison avec les cultes exclusivement masculins caractéristiques de la religion pré-contact, la liturgie chrétienne leur offre plus de possibilités de participation. Cette légitimation de la présence des femmes dans les lieux de cultes se traduit aussi par leur présence dans les arènes sociales villageoises. Avec une emphase sur la famille nucléaire opposée à la famille polygynique traditionnelle à base patrilinéaire, certaines femmes - mais pas toutes - ont acquis plus d'influence sur leurs maris, plutôt que sur leurs beaux-frères ou parents masculins. Cela provoque donc des basculements importants en matière écologique qui sont parfois pilotés par des influences féminines détournées, consistant à pousser de façon indirecte leurs maris vers une décision puisqu'elles-mêmes n'ont pas encore la légitimité sociale de prendre directement et ouvertement ces résolutions.

Le pouvoir politique, décisionnel, économique et rituel est traditionnellement détenu par le kak-hän, (litt. " homme chef») un leader, un personnage de prestige qui doit sa réputation à sa compétence dans la connaissance coutumière et à sa capacité diplomatique dans le règlement des conflits. Avant la pax australiana, la réputation d'un kak-hän dépendait aussi de son prestige comme guerrier. Traditionnellement, les décisions concernant le groupe étaient prises par les kak-hän-s'il s'agissait d'une décision relative à son propre lignage (par exemple : fixer le montant d'un prix de la fiancée) - ou par un ensemble de plusieurs kak-hän - s'il s'agissait des décisions qui concernaient plusieurs groupes ou clans (par exemple : déterminer le droit d'exploitation d'un territoire commun). Les femmes, rappelons-le, n'avaient aucun pouvoir décisionnel. Aujourd'hui, la présence de nouveaux interlocuteurs, notamment le gouvernement (provincial et national) et les compagnies étrangères, est contrebalancée par des intermédiaires appropriés - travailleurs migrants, étudiants, hommes politiques - qui accomplissent une double fonction de médiation et de défense contre les tentatives d'exploitation des communautés indigènes par des agents externes. Néanmoins, toute décision concernant l'exploitation et la conservation 
du patrimoine forestier, quoiqu'influencée par ces trois catégories d'intermédiaires en matière écologique, nécessite également l'approbation définitive des leaders coutumiers. La première catégorie, celle des travailleurs immigrés, est composée d'hommes entre 20 et 40 ans, célibataires ou mariés, qui travaillent et vivent, seuls ou avec leurs familles, principalement à Tabubil, siège de la compagnie minière Ok Tedi Mining Limited. Leur pouvoir est surtout d'information, car ils sont le principal lien entre la communauté villageoise et le monde extérieur. La deuxième catégorie, celle des étudiants, est composée par des jeunes hommes et quelques jeunes femmes qui ont poursuivi leurs études secondaires, voire universitaires, en milieu urbain. L'éducation supérieure permet l'accès au pouvoir décisionnel de ces deux nouvelles catégories sociales n'ayant jamais eu le droit, jusqu'à l'époque précontact, d'intervenir dans des questions concernant la communauté : les jeunes non initiés et les femmes. Leur pouvoir doit être analysé en termes d'influence exercée sur la communauté villageoise dans le sens qu'ils peuvent attribuer plus ou moins d'importance aux différents aspects des problèmes affrontés. La troisième catégorie enfin, celle des politiciens, est formée exclusivement d'hommes adultes qui ont vécu à cheval entre l'époque pré-contact et l'époque d'évangélisation et d'administration du gouvernement australien, commencée pendant les années 1960. Ces individus ont donc eu l'opportunité de bénéficier en même temps du processus de formation traditionnel (initiations) et de l'éducation scolaire (écoles missionnaires et gouvernementales). Par rapport aux deux autres catégories, ce dernier petit groupe de médiateurs poursuit des stratégies structurées de façon à augmenter leur prestige et leur pouvoir personnel. Des hommes politiques oksapmin ont été membres de l'assemblée nationale et du gouvernement provincial (Sandaun Province ${ }^{3}$ ).

Néanmoins, toute décision concernant l'exploitation et la conservation du patrimoine forestier nécessite également l'approbation définitive des leaders coutumiers. L'action de ces derniers doit être intégrée à celle de personnalités officiellement élues : le councillors - porteparole du groupe dans sa totalité - et les community members - qui représentant les différents villages - qui sont élus tous les cinq ans.

Le patrol officer (kiap), qui est un fonctionnaire gouvernemental garant de la loi et de l'ordre de la communauté (Oksapmin) dans le contexte du district (Telefolmin) ou de la province (Vanimo, chef-lieu de la province de Sandaun), n'est pas un individu exerçant une véritable autorité, mais plutôt un porte-parole de l'autorité des leaders traditionnels dans un contexte villageois ou communautaire. Le respect de ses décisions est fonction de son prestige individuel, non de sa charge. La compétence fondamentale d'un community member ou d'un councillor est la connaissance de la langue véhiculaire, le Tok Pisin. Ainsi, des individus, pas nécessairement prestigieux mais pratiquant le Tok Pisin, peuvent accéder à cette charge et représenter les kak-hän, les leaders coutumiers.

Le kiap et les politiques locaux véhiculent l'information sur la politique gouvernementale, provinciale et nationale. Des projets gouvernementaux à petite échelle ont permis la régénération de petites portions de prairie anthropogénique. Inspirés par la politique écologique gouvernementale, les Oksapmin ont repris la plantation des arbres Casuarina sp. dans les jardins pour favoriser l'oxydation du terrain. Mais, hormis ces actions ponctuelles, il n'y a pas chez eux un engagement écologique spontané. Le concept de " développement durable » consiste en une approche du développement entendu comme une aide unilatérale de la part d'institutions nationales. Le concept du giving environment glisse donc de la nature à l'économie en se métamorphosant en un concept de giving development. Les " grands frères blancs » apportent le développement sous la forme d'aides au développement ou d'exploitation minière. À ce propos, il faut rappeler que l'obligation de payer les impôts est généralement évitée par les Oksapmin qui ne voient pas pourquoi ils devraient financer les caisses d'un État absent ou inefficace sur leur territoire. Les bureaux de l'administration, qui avaient été ouvert à partir de 1961 et avaient continué à fonctionner pendant une trentaine d'années, sont désormais fermés. Les quelques fonctionnaires qui restent ne sont pas motivés, car ils n'ont pas d'équipement ni de fournitures et reçoivent leurs salaires de façon très irrégulière. De fait, l'attitude des Oksapmin envers le gouvernement national est celle d'une déception face à une trahison, à un abandon. Pour aggraver la situation, il y a la crainte (réelle) que l'armée (imaginaire) de la plus grande Église occidentale envahisse Oksapmin (Brutti, 1999). Comme résultat de toutes ces causes concomitantes, les habitants de la région du bassin du Strickland et

3. Terme pidgin contraction de sun i go dawn, à la lettre «coucher du soleil», nom qui a été donné à cette province, préalablement appelée West Sepik, à cause du fait que, étant la plus à l'Ouest, elle est la dernière du territoire de Papouasie à voir le coucher du soleil. 
du Lagaip ne souhaitent aucune implication de leur gouvernement, provincial ou national, dans les questions concernant la tenure foncière et ils préfèrent négocier directement avec les compagnies étrangères. Et ils s'attachent spécialement à conclure des affaires avec les compagnies minières car ils savent qu'elles paient bien et régulièrement. Ils ne s'intéressent pas trop à des politiques écologiques protectionnistes. Il semblerait qu'ils ne croient pas que leurs ressources naturelles soient épuisables et limitées dans l'espace et dans le temps, peut-être parce que, historiquement, il n'ont jamais connu de situations comparables. Pour les Oksapmin, le modèle d'environnement généreux a toujours fonctionné jusqu'à aujourd'hui et il n'y a pas de raisons pour qu'il ne continue pas à participer eux aussi aux dynamiques qui lient les autochtones aux compagnies étrangères.

\section{Sur le glissement éco-cosmologique}

Le concept d'environnement généreux trouve donc à Oksapmin ses racines dans la cosmologie pré-contact. En langue oksapmin, il existe des mots pour dire « guerre» (siot), " combattre» (gusupät), mais pas pour dire « paix ». Il n'existe pas non plus, dans le champ des pratiques en relation avec le monde de l'invisible, de mot pour dire « religion », concept occidental récent, créé par la coupure aristotélicienne entre monde sensible et monde transcendantal, entre homme et cosmos, entre objet et sujet. La religion, pour eux, n'est pas un concept séparé de la sphère du social ou du naturel, toute activité envers la nature ou envers les hommes étant imprégnée d'un aspect surnaturel ou, si l'on veut, transcendantal. Dans le travail des jardins, la cueillette, le ramassage, la chasse en forêt, les guerres, les alliances et les rapports sociaux, il y a toujours des références au transcendantal, que ce soit sous forme de culte des ancêtres, ou de propitiation ou crainte des esprits de la forêt et de la terre, ou encore en référence au pouvoir des actions des sorciers vers les êtres humains ou vers la nature. Au risque d'être soupçonné de surinterprétations métaphysiques, l'on pourrait affirmer dans ce sens, que chaque action humaine, qu'elle soit écologique - dirigée vers l'environnement -, ou sociale - dirigée vers les autres êtres humaines -, est un acte " religieux ", dans le sens étymologique du verbe latin re-ligo, relier, reconduire au tout, au cosmos. Dans la cosmologie comme dans les pratiques quotidiennes oksapmin, l'environnement n'est pas distingué de l'homme et l'ordre végétal n'est pas une catégorie séparée de l'ordre animal. Chaque être vivant ou chose inanimée, visible ou invisible hommes, femmes, ordre animal, ordre végétal et minéral comme ce que l'on pourrait appeler, par des termes qui nous sont familiers, "le monde surnaturel »-, est traditionnellement une partie constitutive du cosmos. Toutes ces entités formaient le cosmos traditionnel ou mieux, le cosmos «pré-contact». Les êtres invisibles, qu'ils soient des esprits - par exemple les mong sup, les esprits chtoniens - ou des dieux - par exemple Yuan $k u$ - ne sont pas séparés de l'univers naturel. Toute activité dans la sphère humaine ou naturel est donc imprégnée de religion et de rituel.

Dans la transition de la cosmologie précontact à celle importée, c'est-à-dire le processus de conversion au christianisme, c'est le paradigme de référence qui change, même si certains modes d'expression restent apparemment inaltérés. Dans le cas des Oksapmin, la conversion au christianisme a été un glissement d'un panthéon polymorphe dominé par l'esprit féminin ancestral Yuan ku (Afek en langue telefol), vers le même milieu écocosmologique conquis par le Dieu chrétien importé. La référence polythéiste plus archaïque, représentée par la panoplie d'esprits, reste inaltérée. Les esprits chtoniens (mong sup) existent toujours et continuent leur travail, même dans les représentations des Okspamin convertis. La sorcellerie (tam äm) est encore d'actualité dans cette société. Les fidèles se retrouvent à l'église le samedi ou le dimanche, mais ils ont toujours tendance à attribuer la responsabilité d'un accident, d'une blessure ou d'une quelconque anomalie dans l'ordre physique et social, à la sorcellerie. La sorcellerie a toujours des causes endogènes : le coupable doit être recherché dans le clan car il appartient au même sang que sa victime. Les procès villageois visant à identifier la victime sont fréquents. En appliquant ce principe à la dimension écologique, il est aussi possible de voir comment les nouvelles représentations cosmogoniques ont influencé la praxis cosmologique. Comme Joël Robbins (1995 : 215-217) l'a remarquablement bien souligné, le christianisme a inculqué le concept de la «[...] domination humaine sur la terre et ses fruits, l'idée familière chrétienne de la domination de l'homme sur la nature [...] Ils sont libres de prendre de la nature ce qu'ils veulent et de le consommer comme ils le veulent ${ }^{4} »$. La conversion à la religion chrétienne a 
produit un clivage entre les gens et leur environnement. Les individus se sentent libres d'en user, presque de le violer, pour montrer qu'ils ont abandonné les croyances «fallacieuses» des ancêtres et qu'ils suivent désormais le droit chemin du christianisme. De surcroît, l'introduction de la notion de libre-arbitre par les missionnaires et l'adoption de l'économie de marché importée par les compagnies minières ont déplacé le rôle de la présence humaine dans le milieu forestier. Suite au processus de conversion et à l'accès à la mondialisation, l'humanité est passée du statut de simple élément du cosmos soumis à des contraintes idéologiques et empiriques à celui d'agent actif dominant l'environnement, tant dans les représentations que dans les pratiques. C'est là que la notion d'« environnement généreux » acquiert sa prégnance: l'homme peut tout prendre à cette nature qu'il domine, la nature doit se plier à la volonté humaine et tout donner.

Nous l'avons répété à plusieurs reprises, la société oksapmin est aujourd'hui bouleversée par d'importants changements socioéconomiques et les Oksapmin utilisent leur confession religieuse comme moyen de résolution des conflits sociaux. En un certain sens, la plupart des nouveaux adeptes du christianisme à Oksapmin sont le produit de la première génération acculturée, des individus dès leur enfance éduqués à l'occidental et habitués à la consommation de produits industriels, au travail salarié. Ils ont donc intériorisé des représentations imprégnées du capitalisme et ils se retrouvent potentiellement dans une situation de crise, car ils ont développé un complexe d'infériorité en termes socioéconomiques. Ayant accès au processus de globalisation, ils sont conscients qu'ils sont des citoyens d'un pays avec des problèmes sociaux, économiques et politiques graves, et ils perçoivent comme modèle de référence, en terme d'efficience, d'autres pays anglophone, tels que l'Australie ou les États-Unis. Ces représentations culturelles nous permettent de comprendre combien le discours religieux est entremêlé avec le discours politique et écologique. Pourquoi donc les questions cosmologiques traditionnelles se révèlent si importantes dans les enjeux politiques et écologiques? Comment les anciennes croyances peuvent influencer les représentations et les pratiques relatives aux compagnies minières et à leur impact sur l'environnement?

La première réponse est d'ordre topographique. Dans le temps mythique comme dans le temps chronologique, toute innovation est arri- vée à Oksapmin en provenance de l'Est, des Hauts-Plateaux, en traversant le Strickland, suivant le cours du soleil. Cela a été le cas pour le renouveau cosmologiques apporté par Yuan $\mathrm{ku}$ (Afek), la mère de tous les groupes Min. Cela a été le cas aussi pour l'introduction de la patate douce, comme l'attestent les mythes (Brutti, 2003 : 393). Et, cela a été encore le cas pour les premiers Blancs (Champion, 1966) et, notamment, la patrouille de Black et Taylor qui a pénétré la région (Gammage, 1998) en arrivant aussi des Hauts-Plateaux à travers le Strickland. Plus tard, pendant les années 1960, les premières missions évangéliques qui se sont installées, à Oksapmin venaient de leurs quartiers généraux situés à Mount Hagen. Tout bouleversement dans l'histoire oksapmin est donc arrivé de l'Est, à travers le fleuve qui constitue une frontière naturelle avant d'accéder en pays oksapmin. Cela est significatif pour comprendre, entre autres, pourquoi les suites des opérations de la compagnie Porgera Joint Venture sur le bassin du Strickland ont un impact si important sur les représentations culturelles concernant l'environnement. Ce cas - et ses conséquences - n'est pas unique dans la région. Depuis le début des années 1980, les Oksapmin ont aussi expérimenté l'impact d'une autre grande compagnie minière dans la région, Ok Tedi Mining Limited (OTML). Mais l'érosion du paysage culturel provoqué par OTML sur le mont Fubilan, important dans la cosmologie Min comme étape du voyage mythique d'Afek, a moins affecté les Oksapmin que la pollution et la sédimentation provoquées par la Porgera Joint Venture dans le Strickland. Bien sûr, il y a des raisons pratiques pour cela, surtout liées à la proximité géographique. Le mont Fubilan, à Tabubil, est loin des territoires oksapmin, au moins cinq jours de marche ou une heure de Cessna. Mais la distance géographique n'a jamais constitué un problème à Oksapmin, pourvu qu'il y ait une revendication territoriale. La différence principale consiste dans le fait que le mont Fubilan n'appartient pas aux Oksapmin, contrairement aux berges du Strickland dont ils peuvent constamment témoigner des changements de couleur de l'eau qui vire au pourpre ou de l'érosion des berges de plus en plus importante à cause de la montée du niveau des eaux due à la sédimentation. Les plaintes des Oksapmin ne portent donc pas seulement sur les effets matériels et sur l'impact écologique, mais sur la profanation des sites sacrés et sur la perturbation de l'ordre cosmique, car ce fleuve a toujours eu une importance majeure dans la tradition orale et la cosmologie. 


\section{Et alors?}

Les Oksapmin étant aujourd'hui convertis au christianisme et censés avoir abandonné leurs anciennes pratiques religieuses, y compris les croyances dans les esprits, on pourrait objecter qu'il n'est pas cohérent qu'ils demandent à être indemnisés, pour dommage culturel, pour des éléments qui ne font plus partie de leur culture. Mais cela n'est pas tout à fait exact. En fait, c'est la représentation de cet environnement généreux qui a changé : centré auparavant sur le rapport avec la nature, elle est plus axée aujourd'hui sur les relations avec les nouveaux interlocuteurs étrangers, notamment les compagnies minières. Néanmoins, la situation contemporaine à Oksapmin est plus compliquée et elle ne peut pas être réduite à la simple opposition dualiste passé/présent, religion traditionnelle/évangélisation. Comme dans le cas du rituel de fertilité consacré à Yuan ku, la conversion au christianisme a été un processus superficiel, caractérisé par un intérêt matériel, à travers lequel l'infrastructure cosmologique pré-contact a été consciemment occultée pour laisser la place à la nouvelle religion. Mais les croyances préexistantes n'ont pas totalement disparu; elles ont été cachées à la vue des pasteurs et des Blancs pour ne pas les froisser! Les pratiques de sorcellerie, de divination ou de magie sont toujours très vivantes, puisqu'ayant un rôle capital dans la société et l'histoire culturelle oksapmin, elles ne peuvent pas disparaître en quelques années. Bien que les maisons cérémonielles et les sites sacrés ont été détruits sous la pression des évangélisateurs, bien que les initiations masculines sont interdites, cela ne représente que la pointe de l'iceberg juste poncée pour la niveler. Un corpus énorme de pratiques et de conceptions traditionnelles est aujourd'hui encore actif et n'a pas encore été supprimé par quelques décennies d'évangélisation. Il a été seulement modulé pour répondre aux contraintes socioéconomiques externes apportées par les nouveaux acteurs de la cosmologie dominante. Le seul danger, pour cet iceberg caché, est le temps qui fait disparaître les dépositaires coutumiers de la connaissance avant qu'ils n'aient pu la transmettre à leur descendance.

Sur ces bases, les Oksapmin ont eu gain de cause dans la revendication de l'importance spirituelle de leur fleuve et ils ont été dédommagés pour l'impact écologique ainsi que pour le choc culturel. En fait, la pollution chimique a tué le père des sangliers, un esprits qui vivait dans les eaux du Strickland, alors que l'érosion a effacé les sites sacrés, les traces du passage de la mère
Afek/Yuan $k u$ pendant son voyage ancestral. C'était sur ces berges que les Oksapmin commencèrent, il y a trois siècles, à célébrer le culte Yuan täl et à sacrifier un homme (Yuan hän) pour remercier Yuan $k u$ de les avoir civilisés et pour la prier de continuer à leur donner prospérité et abondance. Bien sûr, on pourrait soupçonner les Oksapmin d'avoir un peu exploité la présence des compagnies pour justifier tous leurs problèmes écologiques ou même culturels. Mais la réalité est plus complexe que cela car l'impact écologique des compagnies s'insère dans le contexte élargi des attentes négatives autour du passage au nouveau millénaire et de la crainte de la fin du monde professée par la plupart des Églises mélanésiennes. Sur la base de ces représentations négatives, chaque bouleversement empirique significatif est automatiquement interprété sur un plan idéologique. Cela a été le cas, par exemple, de macro-phénomènes écologiques tels que la sécheresse de 1997 ou le raz de marée de 1998 sur la côte nord de Papouasie. Les bouleversements écologiques actuels n'échappent pas à la même lecture idéologique et cosmologique. Néanmoins, les Oksapmin continuent d'être enthousiastes à propos de la présence de compagnies privées sur leur territoire car elles apportent de l'argent liquide et un réseau d'infrastructure que le gouvernement national n'a jamais eu la possibilité ou la volonté de fournir à cette région. Bien sûr, les représentations éco-cosmologiques des sociétés autochtones ne sont pas toujours faciles à comprendre et à accepter pour les compagnies multinationales car il s'agit d'une confrontation entre cultures diverses, entre cosmologies différentes et entre intérêts économiques divergents. Aujourd'hui, les tractations entre les Oksapmin et les compagnies minières portent sur les compensations pour les opérations passées ainsi que sur la négociation d'interventions futures. Tout cela suivant un mode de relation à la nature qui correspond à celui d'environnement généreux : dans l'agroforestérie traditionnelle ainsi que dans l'exploitation minière contemporaine, la nature donne sans demander grand chose en échange. Peter Dwyer et Monica Minnegal (1998) ont montré la contingence de ce modèle qui s'articule autour de l'immédiateté et de le réciprocité généralisée. À Oksapmin comme à Gwaimasi, ce modèle est vulnérable et peut $s^{6}$ afaisser. Si les nouveaux venus déçoivent les attentes des autochtones en termes d'immédiateté et de réciprocité généralisée, comme ils semblent commencer à le faire, un sentiment d'abandon et de décentralisation pourrait se développer chez les Oksapmin. 


\section{BIBLIOGRAPHIE}

BIRD-DAVID Nurit, 1990. The giving environment: another perspective on the economic system of hunters-gatherers, Current Anthropology 31, pp. 189-196.

BRUTti Lorenzo, 1997. Waiting for God. Ecocosmological Transformations among the Oksapmin, in Andrew Strathern and Pamela Stewart (eds), Millennial Markers in the Pacific, Townsville, Center for Pacific Studies, James Cook University of North Queensland, pp. 87-131.

—, 1999. On His Holiness' Secret Service. Representations of Catholicism in Contemporary Evangelised Papua New Guinea, in Kristin Cocher-Schmidt, Expecting the day of wrath. Versions of the millennium in Papua New Guinea, Port Moresby, National Research Institute, pp. 44-56.
—, 2003. Qui a tué Afek? Transformations socioéconomiques et continuité culturelle chez les Oksapmin de Papouasie Nouvelle-Guinée, thèse de doctorat en anthropologie sociale et ethnologie, Paris, École des hautes études en sciences sociales.

Champion Ivan F., 1966. Across New Guinea: from the Fly to the Sepik, Sydney, Lansdownee Press.

Dwyer Peter D. and Monica Minnegal, 1998. Waiting for company: Ethos and Environment among the Kubo of Papua New Guinea, Journal of the Royal Anthropological Institute n.s. 4, pp. 23-42.

Gammage Bill, 1998. The Sky Travellers. Journey in New Guinea 1938-1939, Melbourne, Melbourne University Press.

KNAUFT Bruce, 1985. Good company and violence: sorcery and social action in a lowland New Guinea society, Berkeley, University of California Press. 
